Research Article

\title{
Evaluation of physiological and biochemical aberration linked to effect of sodium dodecyl sulphate on barley seedlings
}

\author{
Mucip Genisel ${ }^{1}$. Osman Eren ${ }^{2}$
}

Received: 12 December 2019 / Accepted: 18 February 2020 / Published online: 2 March 2020

(c) Springer Nature Switzerland AG 2020

\begin{abstract}
Sodium dodecyl sulphate (SDS) amount in domestic and industrial effluents is consistently increasing since SDS is available in almost all cleaning products. Therefore, it has become one of the potential destructive factors on habitats such as agricultural areas and aquatic environments. This study was carried out to evaluate the SDS-induced changes on barley (Hordeum vulgare L. Cv. Olgun) seedlings. Barley seedlings were hydroponically cultivated for nine days at optimal conditions and, then, exposed to five different doses of SDS. After $72 \mathrm{~h}$ from SDS addition, root and coleoptile lengths were seriously reduced as compared to control. Also, SDS decreased soluble protein, chlorophyll $a$, chlorophyll $b$ and carotenoid contents of the barley leaves. Furthermore, the SDS-induced reductive effects on protein profiles of barley leaves were also detected with electrophoresis. SDS caused serious decreases in activities of antioxidant enzymes, including superoxide dismutase, catalase, and ascorbate peroxidase and glutathione reductase except for peroxidase. Moreover, the SDS led to the emergence of oxidative damage symptoms that were manifested by the increased superoxide anion formation, hydrogen peroxide content and lipid peroxidation level of barley seedlings. Eventually, the results of the present study revealed that SDS cause to a severe reduction in the growth of barley seedlings.
\end{abstract}

Graphic abstract

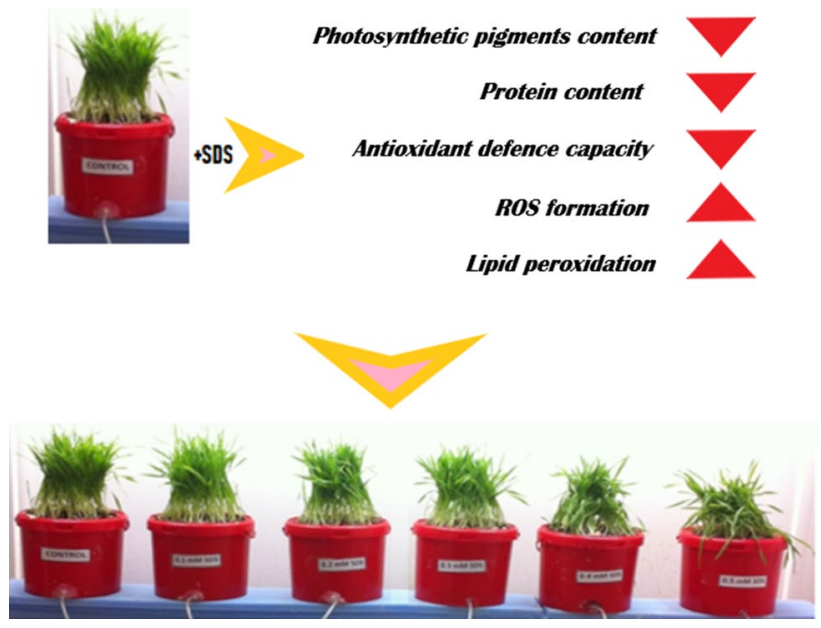

$\triangle$ Mucip Genisel, m.genisel@hotmail.com; Osman Eren, eren2029@hotmail.com | 'Department of Pharmaceutical Botany, Faculty of Pharmacy, Agri Ibrahim Cecen University, Agri, Turkey. ${ }^{2}$ Department of Chemistry, Institute of Natural and Applied Sciences, Agri Ibrahim Cecen University, Agri, Turkey. 
Keywords Sodium dodecyl sulphate · Barley · Antioxidant defence capacity · Cell membrane damage · Protein profile · Ecological risk

\section{Introduction}

Environmental pollution, defined as contamination of air, soil and water by various factors, has always been a serious threat for all organisms. The magnitude of this threat is increasing rapidly with domestic and industrial pollutants day by day [36]. Detergents, commonly used in the domestic and industrial process, are among these environmental pollutant factors [69]. The contamination from the detergent waste of the rivers, lakes and finally agricultural areas leads to irreversible damages at habitats of all organisms $[48,53]$. To reduce this threat, The World Health Organization (WHO) has recommended $0.2 \mathrm{mg} \mathrm{L}^{-1}$ as the maximum detergent residue ratio in water resources [17]. However, it has been detected that the level of the detergent residue in some water resources is about fifty times greater than this critical ratio [13].

Detergents primarily comprise four main components: surfactants, foam regulators, adjuvants and additives [72]. Due to its better surfactant property in comparison to other surfactants, SDS is used in almost all detergents $[5,24]$. It also exists in many products such as solid disinfectants, drug formulations, toothpastes, shampoos, liquid hand soaps, shower gels, shaving foam, floor cleaners, car wash soaps, lotions, laundry and dishwashing detergents (Atıcı 2016). In addition to these, SDS is also used in dentistry, skin softening, wool cleaning, metal processing as well as paint, paper and food industries [38, 42]. Because of its wide utilization and the waste disposal with water, SDS penetrates almost all habitats and inevitably pollutes those areas. Recently, some researchers have reported that the detergent wastes could cause allergic symptoms in organisms $[8,29,39]$. It has also been informed that detergent wastes could negatively affect physiological, biochemical metabolism of aquatic organisms [1, 44, $47,56]$. Additionally, it has also been detected that these wastes trigger the necrosis, chlorophyll degradation, growth retardation in plants $[3,16,62]$. Moreover, SDS, one of the raw material of detergents, leads to the misfolding and denaturation of proteins in cells since it can break down the peptide bonds of amino acids by loading with the negative charge to them $[25,55]$.

Unlike other organisms, plants are the sessile organisms, and therefore they are much more affected by various stress factors such as salt, cold, heat, drought and heavy metal. Those stress factors lead to troubles in the electron transport chain of organelles, and this situation results in overproduction of reactive oxygen species (ROS) in their cells.

\section{SN Applied Sciences}

When ROS are at low concentrations in the cytoplasm, they can play a role in cellular signalling events. However, excessive ROS seriously damage the membranes of cell and organelles. Therefore, ROS amounts in cells have to be stabilized by antioxidant enzymes such as superoxide dismutase (SOD), catalase (CAT), ascorbate peroxidase (APX), glutathione reductase (GR) and peroxidase (POX) as well as non-enzymatic antioxidants containing ascorbate and glutathione.

Many studies have been focused on the relationship between antioxidant enzyme activities and plant tolerance against the stressors such as salt, cold, hot and heavy metals $[66,67,59-65,59,58]$. Although SDS is a serious threat agent on plant growth, there are very limited studies about the toxic effects of SDS on plants. In these studies, it has been reported that SDS led to an important decrease in the growth rates and chlorophyll contents of duckweed and water fern $[26,27]$. Another study has also revealed that the SDS caused the serious declines in biomass, germination percentage, CAT activity and protein content in wheat [19]. However, there is no study evaluating the effects of SDS-induced changes in protein profile, free radical and membrane damage of plants.

Over the recent years, the level and number of stress factors have been increasing in agricultural areas; therefore, limitations in yield and production of crops are rapidly growing. $[12,15]$. Detergents, among these stress factors, are abundant in domestic and industrial wastewater and lead to the destructions in biological activities of organisms by disturbing oxygen transport in the water and soil [48]. Therefore, the detergent wastes are potential risk factor for plants. The toxic effects of detergents on living organisms arise from SDS which is the anionic raw material of almost all of the cleaning products [5]. In the present study, to contribute to the literature in these regards, it was evaluated the effects of SDS on antioxidant, biosynthesis and biochemical mechanisms of barley seedlings. Also, it was aimed to draw attention to the necessity of precautions to minimize the leakage of SDS into the natural environment from domestic and industrial wastewaters. 


\section{Materials and methods}

\subsection{Plant materials, growth conditions and treatments}

Barley seeds (Hordeum vulgare L. cv. Olgun) were provided by East Anatolian Agricultural Research Institute. All chemicals used in the research were purchased from Sigma-Aldrich. The seeds were surface sterilized with $5 \%$ sodium hypochlorite ( $\mathrm{v} / \mathrm{v})$ for $5 \mathrm{~min}$, and then, they were washed five times deionized water. The seeds were planted in hydroponic systems containing Hoagland solution, aerated continuously with oxygen pumps [4]. The experiment was carried out in a greenhouse, under controlled conditions of humidity $(70 \%)$, temperature $\left(20-23^{\circ} \mathrm{C}\right)$, photosynthetic active radiation $\left(60 \mu \mathrm{m} \mathrm{m}^{-2} \mathrm{~s}^{-1}\right)$ and photoperiod (16-h light/8-h dark). In this experiment, the cultivation, application and harvest times for the barley seedlings times were decided by many preliminary studies. In preliminary experiments, the nine-day seedlings were divided into five groups: only Hoagland (control); Hoagland plus SDS at four different concentrations $(0.5,1,1.5,2 \mathrm{mM})$. SDS concentrations were adjusted according to the volume of the Hoagland. After $72 \mathrm{~h}$ from SDS applications, it was detected that the root and shoot lengths of barley seedlings were reduced at the same rate with three SDS applications $(1,1.5,2 \mathrm{mM})$ except for $0.5 \mathrm{mM}$. Following this experiment, to determine the phytotoxic effects of SDS amounts lower than $0.5 \mathrm{mM}$, a new experimental setup was designed in the same conditions.

In this new experiment, $0.1,0.2,0.3,0.4$ and $0.5 \mathrm{mM}$ SDS were applied to the nine-day barley seedlings and $72 \mathrm{~h}$ after applications, the seedlings were harvested. Seven replicates were prepared from six plants for each application. The tissue replicates $(0.2 \mathrm{~g})$ were grinded in liquid nitrogen and stored in the deep freeze $\left(-80^{\circ} \mathrm{C}\right)$ for analyses.

\subsection{Determination of protein content and profile}

Protein contents of the leaf samples were performed according to the method of Bradford [14]. The leaf tissues were homogenized in $0.1 \mathrm{M}$ phosphate buffer $(\mathrm{pH} 6.75)$ after they were ground in liquid nitrogen. The homogenate was centrifuged at $15,000 \mathrm{rpm}$ for $20 \mathrm{~min}$ and at $4{ }^{\circ} \mathrm{C}$. Absorbance values of the supernatants were recorded at $595 \mathrm{~nm}$. Results were expressed as $\mathrm{mg} \mathrm{g}^{-1} \mathrm{FW}$ and calculated through a calibration curve prepared with standard solutions of well concentration of bovine serum albumin.

Protein profile was detected with the method described by Laemmli [43]. The leaf samples were homogenized with $125 \mathrm{mM}$ Tris $\mathrm{HCl}(\mathrm{pH}$ 6.8) containing $10 \%(\mathrm{v} / \mathrm{v})$ glycerol, $2 \%$ sodium dodecyl sulphate (SDS), $0.1 \%$ bromophenol blue and 5\% 2-mercaptoethanol. After the homogenates were centrifuged at $15,000 \mathrm{rpm}$ for $15 \mathrm{~min}$ at $4{ }^{\circ} \mathrm{C}$, they were kept in water at $90^{\circ} \mathrm{C}$ for $5 \mathrm{~min}$ and cooled at room conditions. Protein bands were separated in 4-11\% SDS-polyacrylamide gel (SDS-PAG) at $120 \mathrm{~V}$. The polyacrylamide gel was stained by using Coomassie brilliant blue R-250. After the gel washing operations, protein bands were displayed.

\subsection{Determination of pigment contents}

The amount of chlorophyll $a$, chlorophyll $b$ and carotenoids were determined with the method of Witham et al. [71]. Leaf tissues were homogenized in $80 \%$ acetone, and then the final volume of the homogenate was completed to $8 \mathrm{~mL}$ with $80 \%$ acetone. The homogenate was centrifuged at $3500 \mathrm{rpm}$ for $7 \mathrm{~min}$ at $4{ }^{\circ} \mathrm{C}$. The absorbance values of the supernatants were recorded at 450, 645 and $663 \mathrm{~nm}$. The photosynthetic pigment amounts were calculated to be $\mathrm{mg} \cdot \mathrm{g}^{-1} \mathrm{FW}$ according to the equivalents described by Witham.

\subsection{Determination of antioxidant enzyme activities}

Leaf samples $(0.2 \mathrm{~g})$ were grinded in liquid nitrogen and homogenized in $2 \mathrm{~mL}$ of $10 \mathrm{mM}$ phosphate buffer $(\mathrm{pH}$ 7.0) containing $1 \mathrm{mmol} \mathrm{L}^{-1}$ ethylenediaminetetraacetic acid (EDTA) and $4 \%(\mathrm{w} / \mathrm{v})$ polyvinylpyrrolidone. After the homogenate was centrifuged at 15,000 rpm for $15 \mathrm{~min}$ at $4{ }^{\circ} \mathrm{C}$, the supernatant was used as the source for antioxidant enzymes.

SOD activity was determined by using the photochemical method described by Agarwal and Pandey [2]. This method is based on the determination of the photochemical reduction in formazan of nitro-blue tetrazolium (NBT) at $560 \mathrm{~nm}$. One unit of SOD activity was accepted as the amount of enzyme causing photoreduction by $50 \%$ of NBT.

For determination of POX activity, it was used to the method described by Ye et al. [73]. According to this method, it was monitored the absorbance increase at $470 \mathrm{~nm}$ arisen from reacting of guaiacol, $\mathrm{H}_{2} \mathrm{O}_{2}$ and peroxidase. The amount of enzyme that increased 0.01 the absorbance value per minute is expressed as one unit of POX enzyme activity.

CAT activity was measured according to the method described by Gong et al. [30]. The method is based on the monitoring of the absorbance changes at $240 \mathrm{~nm}$ during $\mathrm{H}_{2} \mathrm{O}_{2}$ decomposition. According to the method, one-unit CAT activity is accepted as the amount of 
enzyme required to decompose $1 \mu \mathrm{mol}_{2} \mathrm{O}_{2}$ per minute at $25^{\circ} \mathrm{C}$ by using standard graphic.

APX activity was detected according to the method described by Nakano and Asada [52]. The changes of absorbance at $290 \mathrm{~nm}$ were determined. APX activity was calculated by using epsilon coefficient $2.8 \mathrm{mM}^{-1} \mathrm{~cm}^{-1}$ for ascorbic acid.

GR activity measurement was performed according to the method of Foyer and Halliwell [28]. This method is based on the determination at $340 \mathrm{~nm}$ of NADPH oxidation during the conversion of oxide glutathione to glutathione by GR using NADPH as an electron donor. One unit of GR was expressed as the reduction in $1 \mathrm{mmol} \mathrm{mL}{ }^{-1}$ oxidized glutathione (GSSG) per minute.

\subsection{Determination of the hydrogen peroxide $\left(\mathrm{H}_{2} \mathrm{O}_{2}\right)$ amount}

The quantification of $\mathrm{H}_{2} \mathrm{O}_{2}$ amount was performed based on a modified version of the method described by Sergiev et al. [57]. Frozen leaf samples were homogenized in $0.1 \% \mathrm{TCA}$, and then the homogenate was centrifuged at $12,500 \mathrm{rpm}$ for $15 \mathrm{~min}$ at $4{ }^{\circ} \mathrm{C}$. The supernatant was mixed with the equal volume of $10 \mathrm{mM} \mathrm{KH}_{2} \mathrm{PO}_{4}(\mathrm{pH}: 7.0)$ buffer and the double volume of $\mathrm{KI}$ solution. Absorbance values of the mixture and blind were recorded at $390 \mathrm{~nm}$. $\mathrm{H}_{2} \mathrm{O}_{2}$ contents were calculated as $\mu \mathrm{g} \cdot \mathrm{g}^{-1} \mathrm{FW}$ based on the standard graph prepared by adding different concentrations of $\mathrm{H}_{2} \mathrm{O}_{2}$ solution within blind samples.

\subsection{Determination of the superoxide $\left(\mathrm{O}_{2}^{-}\right)$anion amount}

The determination of the superoxide anion amount was accomplished by following the method of Elstner and Heupel [23]. Leaf samples were homogenized in $0.9 \mathrm{~mL}$ $\mathrm{K}_{2} \mathrm{HPO}_{4}$ buffer ( $\mathrm{pH}$ 7.8). The homogenate was centrifuged at $12,500 \mathrm{rpm}$ for $12 \mathrm{~min}$ at $4^{\circ} \mathrm{C}$. The supernatants $(350 \mu \mathrm{L})$ were incubated with $35 \mu \mathrm{L}$ of $10 \mathrm{mM}$ hydroxylamine hydrochloride and $315 \mu \mathrm{L}$ of $\mathrm{K}_{2} \mathrm{HPO}_{4}$ for $60 \mathrm{~min}$ at $25^{\circ} \mathrm{C}$. The centrifugation process was repeated, and then, $17 \mathrm{mM}$ aminobenzene sulphonic acid and $17 \mu \mathrm{M}$ of $350 \mu \mathrm{L}$ a-naphthylamine in equal volumes were added to the mixture. The final mixtures were incubated at room temperature for $60 \mathrm{~min}$. The specific absorbance values of the mixtures were recorded at $530 \mathrm{~nm}$. The results were expressed as $\mu \mathrm{g} \cdot \mathrm{g}^{-1} \mathrm{FW}$ and calculated through a calibration curve prepared with standard solutions of well concentration of $\mathrm{NaNO}_{2}$.

\subsection{Determination of lipid peroxidation level}

Lipid peroxidation levels were determined according to the method described by Heath and Packer [34]. Leaf tissue $(0.2 \mathrm{~g})$ was homogenized in $1.2 \mathrm{~mL}$ of $0.1 \%$ trichloroacetic acid (TCA). The homogenate was centrifuged at $12,500 \mathrm{rpm}$ for $15 \mathrm{~min} .1 \mathrm{~mL}$ of $0.5 \%$ thiobarbituric acid (TBA) in $0.1 \%$ TCA solution was mixed with $500 \mu \mathrm{L}$ of the supernatant. The mixtures were incubated in boiling water for $40 \mathrm{~min}$ and then cooled in an ice cap. They were centrifuged again at $12,000 \mathrm{rpm}$ for $5 \mathrm{~min}$. The absorbance values of samples were recorded at $532 \mathrm{~nm}$ and $600 \mathrm{~nm}$. Malondialdehyde (MDA) amounts were calculated by using the extinction coefficient of $155 \mathrm{mM}^{-1} \mathrm{~cm}^{-1}$.

\subsection{Statistical analysis}

The data are the mean of six repetitions for each application. The data were analysed by using one-way ANOVA and compared with Duncan's multiple comparison at $p<0.05$ significance level with SPSS 20 . Standard errors were indicated in all the tables.

\section{Results}

\subsection{Root and coleoptile lengths}

When looking to Figs. 1 and 2, it is clear that SDS induced morphological changes on the barley seedlings. The root length in the $0.1 \mathrm{mM}$ SDS application was $0.2 \%$ higher than the control, but this increase was not statistically significant $(p>0.05)$. On the other hand, other SDS applications $(0.2,0.3,0.4$ and $0.5 \mathrm{mM})$ caused a decline by 5,8 , 14 and $19 \%$ in the root length, respectively $(p<0.05)$. The SDS-induced symptoms in coleoptiles lengths were similar to those of root lengths. Indeed, when compared to control, $0.1,0.2,0.3,0.4$ and $0.5 \mathrm{mM}$ SDS seriously reduced by $5,11,14,18$ and $19 \%$ the coleoptiles lengths, respectively $(p<0.05)$.

\subsection{Soluble protein contents}

As given in Table 1, when compared to control, soluble protein contents in SDS groups exhibited a downward trend. The protein amounts in $0.1,0.2,0.3,0.4$ and $0.5 \mathrm{mM}$ SDS applications were determined to be less approximately 4 , $7,7,8$ and $8 \%$ than in control, respectively $(p<0.05)$. When looking to Fig. 3 , it is clearly seen that the SDS applications induced significant changes as manifested by the different intensity of protein bands in relation to the control. In SDS dose-dependent manner, while the densities of the bands in the area (50-60 kDa) corresponding to RuBisCO were 
Fig. 1 Effects of SDS application on root and coleoptile lengths of barley seedlings. Different letters in same groups indicate statistically significant differences $(p<0.05)$
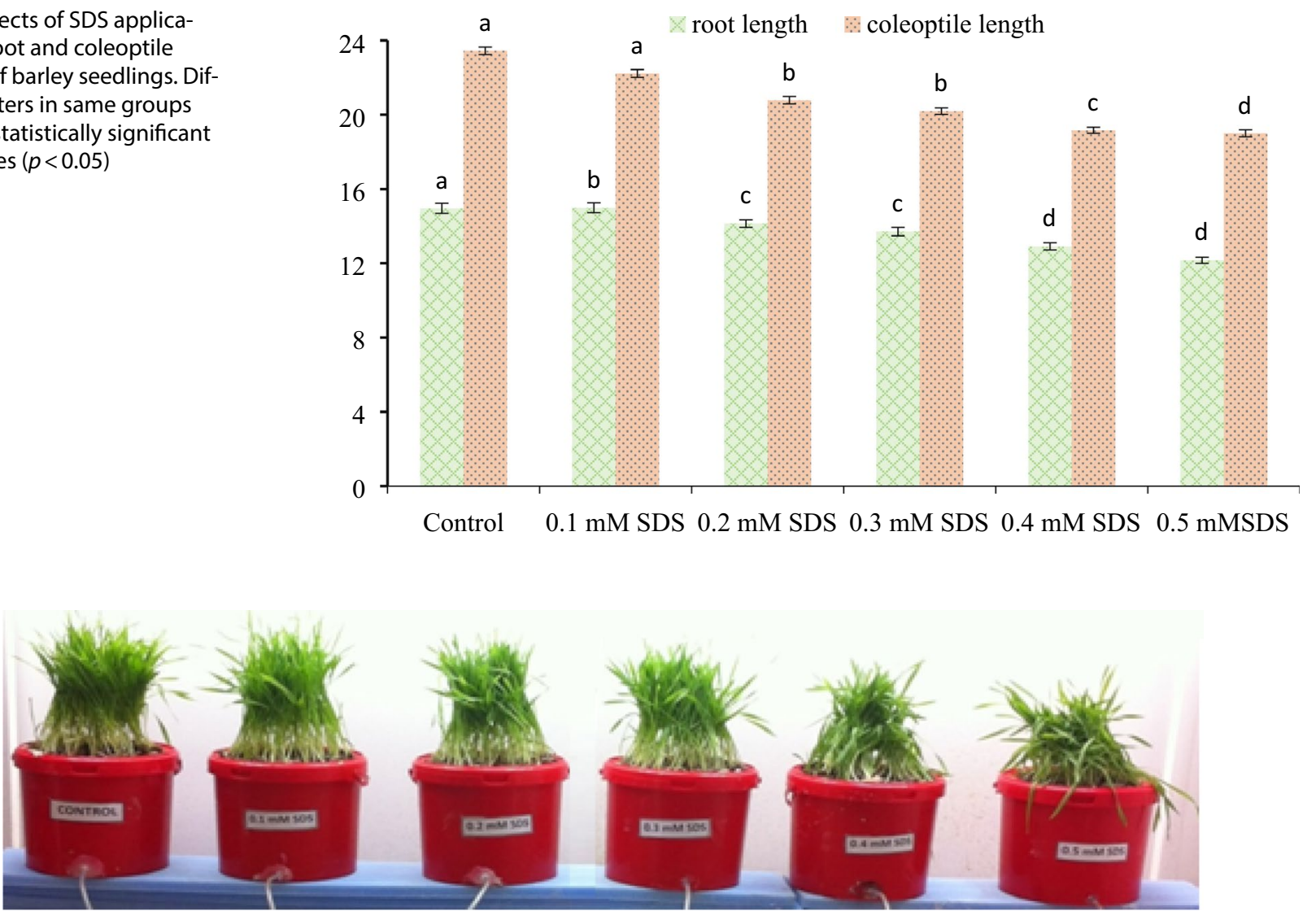

Fig. 2 Digital photographs of barley seedlings after $72 \mathrm{~h}$ from SDS applications

Table 1 Effects of SDS applications on the contents of protein and photosynthetic pigments of the barley leaves

\begin{tabular}{lclll}
\hline Treatments & Protein $\left(\mathrm{mg} \mathrm{g}^{-1} \mathrm{FW}\right)$ & $\begin{array}{l}\text { Chlorophyll } a \\
\left(\mathrm{mg} \mathrm{g}^{-1} \mathrm{FW}\right)\end{array}$ & $\begin{array}{l}\text { chlorophyll } b \\
\left(\mathrm{mg} \mathrm{g}^{-1} \mathrm{FW}\right)\end{array}$ & Carotenoid $\left(\mathrm{mg} \mathrm{g}^{-1} \mathrm{FW}\right)$ \\
\hline Control & $15.52 \pm 0.01 \mathrm{a}^{*}$ & $6.08 \pm 0.03 \mathrm{a}$ & $2.47 \pm 0.02 \mathrm{a}$ & $5.23 \pm 0.04 \mathrm{a}$ \\
$0.1 \mathrm{SDS}$ & $14.96 \pm 0.03 \mathrm{~b}$ & $4.94 \pm 0.02 \mathrm{~d}$ & $1.95 \pm 0.08 \mathrm{~d}$ & $3.76 \pm 0.03 \mathrm{bc}$ \\
$0.2 \mathrm{SDS}$ & $14.5 \pm 0.01 \mathrm{c}$ & $4.91 \pm 0.04 \mathrm{~d}$ & $2.09 \pm 0.03 \mathrm{c}$ & $3.81 \pm 0.05 \mathrm{~b}$ \\
$0.3 \mathrm{SDS}$ & $14.4 \pm 0.01 \mathrm{~d}$ & $5.45 \pm 0.04 \mathrm{~b}$ & $2.21 \pm 0.05 \mathrm{~b}$ & $3.86 \pm 0.11 \mathrm{~b}$ \\
$0.4 \mathrm{SDS}$ & $14.33 \pm 0.03 \mathrm{e}$ & $5.14 \pm 0.06 \mathrm{c}$ & $2.12 \pm 0.03 \mathrm{c}$ & $3.62 \pm 0.05 \mathrm{bc}$ \\
$0.5 \mathrm{SDS}$ & $14.32 \pm 0.02 \mathrm{e}$ & $4.49 \pm 0.05 \mathrm{e}$ & $1.93 \pm 0.02 \mathrm{~d}$ & $3.54 \pm 0.13 \mathrm{c}$ \\
\hline
\end{tabular}

*Different letters in the same column indicate statistically significant differences $(p<0.05)$ seriously reduced, the intensities of the low molecular weight (15-25 kDa) bands containing the stress proteins were significantly increased.

\subsection{Photosynthetic pigment contents}

Pigment analysis results showed that the control group had the highest pigment contents (Table 1). When compared to the control, all of the SDS applications caused the dramatic reductions in the chlorophyll $a$ (by 19, 19, 10, 15 and $26 \%$ ), chlorophyll $b$ (by 21, 16, 11, 14 and $22 \%$ ) and carotenoid contents (by 18, 26, 14, 19 and 33\%) $(p<0.05)$.

\subsection{Antioxidant enzyme activities}

The SOD activity has exhibited an increase in 0.1 and $0.2 \mathrm{mM}$ SDS applications as compared to control. However, the increase in 0.2 SDS was statistically meaningless $(p>0.05)$. On the other hand, the values of SOD activity in $0.3,0.4$ and $0.5 \mathrm{mM}$ SDS were notably lower than that of control (Table 2$)(p<0.05)$. After the SDS applications, POX activities were markedly increased relative to the control $(p<0.05)$. The highest increase in about $93 \%$ was detected in response to $0.5 \mathrm{mM}$ SDS. CAT activities were markedly lower than that of control. When compared to control, the 


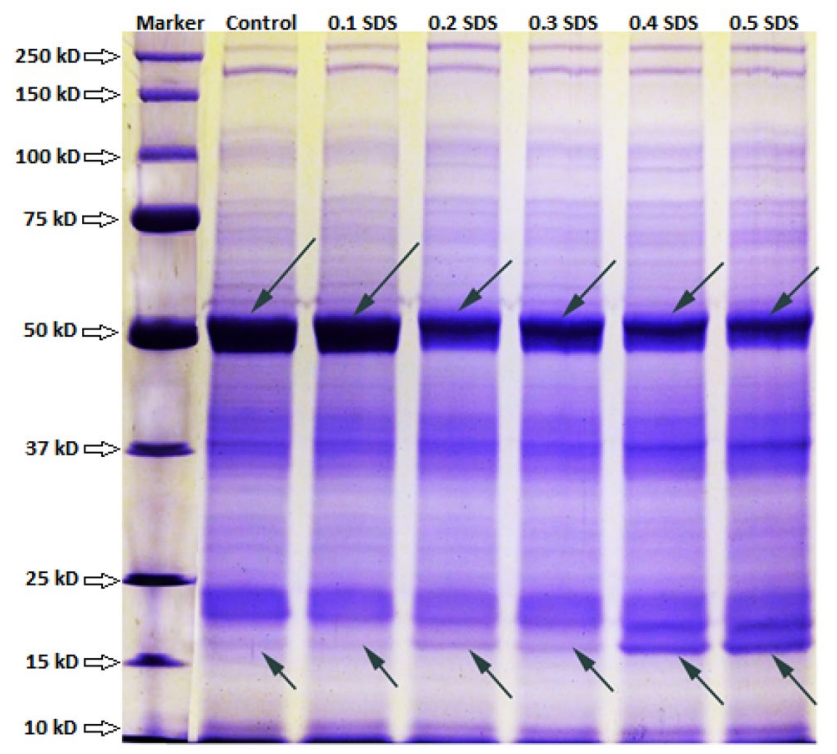

Fig. 3 Effects of SDS application on protein profiles of barley leaves

reductions in the CAT activities were recorded by 47,69 , $65,76$ and $68 \%$, respectively (Table 2$),(p<0.05)$. When looking to Table 2, APX activity was also exhibited the significant decline trends in SDS-treated plants relative to control $(p<0.05)$. However, the decline ratios in APX activity as compared to control were almost the same among all of the SDS application. As compared to the control, GR activity was also reduced about $10 \%$ in 0.1 SDS, $12 \%$ in 0.2 SDS, $16 \%$ in 0.3 SDS, $28 \%$ in 0.4 SDS and $24 \%$ in 0.5 SDS $(p<0.05)$.

\section{5 $\mathrm{H}_{2} \mathrm{O}_{2}$ content and superoxide anion $\left(\mathrm{O}_{2}^{-}\right)$ production}

As can be seen in Table 3, the lowest values of superoxide anion and $\mathrm{H}_{2} \mathrm{O}_{2}$ were recorded in the control. When compared to the control, SDS applications led to critical increases in superoxide anion content. Also, in a dosedependent manner, SDS applications seriously increased
Table 3 Effects of SDS applications on the contents of superoxide anion, hydrogen peroxide and MDA of the barley leaves

\begin{tabular}{lllr}
\hline Treatments & $\begin{array}{l}\text { Superox- } \\
\text { ide anion } \\
\left(\mu \mathrm{g} \mathrm{g}^{-1} \mathrm{FW}\right)\end{array}$ & $\begin{array}{l}\text { Hydrogen } \\
\text { peroxide } \\
\left(\mu \mathrm{g} \mathrm{g}^{-1} \mathrm{FW}\right)\end{array}$ & MDA (nmol g $\left.{ }^{-1} \mathrm{FW}\right)$ \\
\hline Control & $24.27 \pm 0.77 \mathrm{c}^{*}$ & $22.52 \pm 0.28 \mathrm{f}$ & $4.84 \pm 0.05 \mathrm{e}$ \\
$0.1 \mathrm{SDS}$ & $28.55 \pm 0.41 \mathrm{~b}$ & $23.83 \pm 0.18 \mathrm{e}$ & $5.12 \pm 0.04 \mathrm{e}$ \\
$0.2 \mathrm{SDS}$ & $32.85 \pm 0.61 \mathrm{a}$ & $26.91 \pm 0.07 \mathrm{~d}$ & $5.99 \pm 0.23 \mathrm{~d}$ \\
$0.3 \mathrm{SDS}$ & $32.32 \pm 0.51 \mathrm{a}$ & $28.1 \pm 0.12 \mathrm{c}$ & $6.85 \pm 0.08 \mathrm{c}$ \\
$0.4 \mathrm{SDS}$ & $32.9 \pm 0.37 \mathrm{a}$ & $43.77 \pm 0.69 \mathrm{~b}$ & $12.25 \pm 0.49 \mathrm{~b}$ \\
$0.5 \mathrm{SDS}$ & $31.33 \pm 0.28 \mathrm{a}$ & $51.15 \pm 0.28 \mathrm{a}$ & $15.05 \pm 0.16 \mathrm{a}$ \\
\hline
\end{tabular}

*Different letters in the same column indicate statistically significant differences $(p<0.05)$

the $\mathrm{H}_{2} \mathrm{O}_{2}$ content. The highest value of $\mathrm{H}_{2} \mathrm{O}_{2}$ content was measured in $0.5 \mathrm{mM}$ SDS (an approximate increase of $127 \%)$ relative to the control $(p<0.05)$.

\subsection{Lipid peroxidation levels}

MDA is accepted as one of the important indicators of lipid peroxidation. In the present experiment, all of the SDS applications except for $0.1 \mathrm{mM}$ SDS have critically increased the lipid peroxidation level. When compared to the control, the MDA contents in $0.2,0.3,0.4$ and $0.5 \mathrm{mM}$ SDS applications increased by approximately $24,42,153$ and $210 \%$, respectively (Table 3$)(p<0.05)$.

\section{Discussion}

In the present study, it was aimed to evaluate as the physiological and biochemical the effects of SDS on the barley seedlings. As far as we know, only a few works have explored the effects of SDS on plants. Also, this is the first study which reveals the SDS-induced changes on barley seedlings. Therefore, it is expected that this study will provide important contributions to the literature.

Table 2 Effects of SDS applications on the activities of superoxide dismutase (SOD), peroxidase (POX) and catalase (CAT), ascorbate peroxidase (APX) and glutathione reductase (GR) of the barley leaves

\begin{tabular}{lcllll}
\hline Treatments & SOD $\left(\mathrm{U} \mathrm{mg}^{-1}\right.$ protein $)$ & POX $\left(\mathrm{U} \mathrm{mg}^{-1}\right.$ protein $)$ & CAT $\left(\mathrm{U} \mathrm{mg}^{-1}\right.$ protein $)$ & APX $\left(\mathrm{U} \mathrm{mg}^{-1}\right.$ protein $)$ & GR $\left(\mathrm{U} \mathrm{mg}^{-1}\right.$ protein $)$ \\
\hline Control & $5.23 \pm 0.09 \mathrm{bc} \mathrm{c}^{*}$ & $1580 \pm 32.2 \mathrm{f}$ & $39.06 \pm 2.62 \mathrm{a}$ & $5.23 \pm 0.04 \mathrm{a}$ & $6.5 \pm 0.17 \mathrm{a}$ \\
$0.1 \mathrm{SDS}$ & $5.7 \pm 0.23 \mathrm{a}$ & $1838 \pm 32.8 \mathrm{e}$ & $20.61 \pm 0.53 \mathrm{~b}$ & $3.76 \pm 0.03 \mathrm{bc}$ & $5.86 \pm 0.22 \mathrm{~b}$ \\
$0.2 \mathrm{SDS}$ & $5.37 \pm 0.05 \mathrm{ab}$ & $2071 \pm 26.7 \mathrm{~d}$ & $11.92 \pm 0.38 \mathrm{c}$ & $3.81 \pm 0.05 \mathrm{~b}$ & $5.74 \pm 0.04 \mathrm{~b}$ \\
$0.3 \mathrm{SDS}$ & $4.95 \pm 0.05 \mathrm{c}$ & $2231 \pm 35.5 \mathrm{c}$ & $13.75 \pm 0.38 \mathrm{c}$ & $3.86 \pm 0.11 \mathrm{~b}$ & $5.49 \pm 0.17 \mathrm{~b}$ \\
$0.4 \mathrm{SDS}$ & $4.39 \pm 0.03 \mathrm{~d}$ & $2480 \pm 42.1 \mathrm{~b}$ & $9.3 \pm 1.2 \mathrm{c}$ & $3.62 \pm 0.05 \mathrm{bc}$ & $4.71 \pm 0.06 \mathrm{c}$ \\
$0.5 \mathrm{SDS}$ & $3.7 \pm 0.09 \mathrm{e}$ & $3054 \pm 59.7 \mathrm{a}$ & $12.7 \pm 2.42 \mathrm{c}$ & $3.54 \pm 0.13 \mathrm{c}$ & $4.92 \pm 0.11 \mathrm{c}$ \\
\hline
\end{tabular}

*Different letters in the same column indicate statistically significant differences $(p<0.05)$ 


\subsection{Effects of SDS applications on root and coleoptile growth}

The results of the present study clearly showed that SDS applications lead to negative effects in normal growth of barley, inducing a decrease in root and coleoptile lengths. It was also determined that the levels of reduction in growth exhibited a positive correlation with the increase in SDS dosage. As compatible with our results, Chang et al. [19] reported that SDS reduced the growth of wheat. It is possible that the SDS-induced growth retardation is due to destructions on the synthesis reactions. After SDS applications, the declines in protein content of barley seedlings study support this situation. It is well known that sodium, a raw component of SDS, is toxic for plants [60]. Therefore, initially, the toxic effects of SDS might be attributed to its sodium content. However, Tuna et al. [70] reported that the sodium-induced the growth retardations in different barley varieties occur at the very higher concentration than sodium content of SDS used in this study. In the present case, it cannot be expressed that the SDS-induced retardations in the barley growth arose from sodium cation. On the other hand, when sulphate, another component of SDS, is at a high amount in the cells, it leads to disruption of the intracellular colloidal structure. In such a case, excessive sulphate in plant tissues will retard the plant growth by disrupting the processes of synthesis reactions and the cell division [18]. In this study, the results of protein content have already shown that biosynthesis reactions strongly affected by SDS.

\subsection{Effects of SDS applications on soluble protein content and protein profiles}

Proteins have many functions from catalytic activity to defence in organisms. Recently, diverse studies have revealed the effects of SDS on proteins. Rajagopal et al. [55] reported that SDS increased the denaturation of bacterial proteins. Also, it was determined in vitro that SDS breaks down the peptide bonds in amino acids and therefore denatures the proteins [25]. Our results clearly pointed out that SDS led to the critical decline in soluble protein content, corroborating previous result recorded for wheat grown in the presence of SDS [19].

The possible cause of these declines could be the disruptions in the cellular metabolic events during transcription, translation and post-translation. Previous studies also showed that SDS-induced decreases in plant protein contents are associated with the disruption of peptide bonds after translation $[19,22]$. Along with protein content, the protein profile images obtained from electrophoresis confirmed the negative effects of SDS on protein biosynthesis. When looking to Fig. 3, it can be clearly seen that SDS caused a decrease in densities of protein bands among $50-60 \mathrm{kDa}$. it is well known that these band ranges are the location of ribulose 1-5 bisphosphate carboxylase oxygenase (RuBisCO) that is the key enzyme in photosynthesis [40]. Therefore, the decline in this protein bands may an indicator of the SDS-induced retardation of the photosynthesis process. On the other hand, the intensities of protein bands under the $25 \mathrm{kDa}$ significantly increased with SDS applications (Fig. 3). It is well known that a lot of stress proteins are located among these protein bands and, the increase of these proteins is one of the plant defence strategies against stress conditions [45].

\subsection{The effects of SDS applications on photosynthetic pigment contents}

For the ecological balance as well as plant development, the continuation of photosynthesis is essential but this metabolic process is adversely affected by stress factors such as drought, salt and heavy metal $[20,63]$. The deteriorations of chlorophyll $a$ and chlorophyll $b$ are accepted as an indicator of the reduced photosynthetic efficiency [33]. The results of the present study shown that the SDSinduced symptoms on photosynthesis manifested as the critical declines in chlorophyll $a$ and b contents. These results are in accordance with a previous work, which showed that SDS declined the chlorophyll contents in duckweed [27]. In this way, the detrimental effect of SDS on pigments may be associated with the SDS-induced disruption in the chlorophyll-protein complex and/or separation of magnesium from chlorophyll centre [62]. In the present study, the content of carotenoids, considered to perform as the accessory pigment for photosynthesis, was markedly decreased by SDS applications. The carotenoids have also antioxidant properties due to a large number of double bonds in their linear molecular structure, and therefore, they can directly scavenge the reactive oxygen particles [54]. In that case, the decrease in carotenoid content might have been led a reduction in the total antioxidant defence capacity against SDS-induced oxidative damage of the barley seedlings.

\subsection{Effect of SDS applications on the antioxidant defence system}

In plant cells, the level of ROS is controlled by the antioxidant enzymes such as superoxide dismutase (SOD), catalase (CAT), ascorbate peroxidase (APX), peroxidase (POD), glutathione reductase (GR) and by the antioxidant substances such as ascorbate and glutathione. However, the power of this defence system may not be enough for their elimination due to the excessive formation of the ROS 
under stress conditions. In this case, the ROS lead to the oxidative damages on all cell components $[32,50]$.

SOD forms the first line of the enzymatic defence mechanism against oxidative damage and has a role in reducing of superoxide anion to hydrogen peroxide $[32,50]$. In the present study, the SOD activities were generally diminished by the SDS applications except for 0.1 and $0.2 \mathrm{mM}$ SDS. Meanwhile, the SOD and superoxide anion data indicate that although the highest SOD activity was measured in $0.1 \mathrm{mM}$ SDS application, this increase in SOD activity was insufficient for detoxification of superoxide anions. On the other hand, in other SDS groups, SOD activities were very low than control. When considered that SDS can damage peptide bond among amino acids, the reductions in SOD activities can be attributed to degradation of the active molecular structure of the enzyme by SDS [25].

The exposure of barley to SDS led to different effects in activities of antioxidant enzymes such as POD, CAT, APX and $G R$, which are responsible for detoxification of $\mathrm{H}_{2} \mathrm{O}_{2}$ [31]. SDS applications caused the activation of POX. This activation might arise from stimulation of the defence mechanism against the SDS-induced oxidative stress. However, it is clear that this activation alone could not prevent the SDS-induced increases in $\mathrm{H}_{2} \mathrm{O}_{2}$ amounts.

Unlike POX, the activity of CAT, responsible for the prevention of the hydroxyl radical formation by catalysing the conversion of $\mathrm{H}_{2} \mathrm{O}_{2}$ into water and oxygen [6], was seriously reduced by SDS applications. This result has corroborated the result of a previous study which recorded a decline of CAT activity in wheat in the presence of SDS [19]. After the exposure of plants to SDS, the inactivation of CAT might result from the separation from the enzyme molecules of the hem groups which is essential for CAT activation $[41,68]$.

APX and GR have significant roles in reducing the $\mathrm{H}_{2} \mathrm{O}_{2}$ into the water at the ascorbate-glutathione cycle which is active in mitochondria, chloroplasts, cytosol and peroxisomes [49]. Besides $\mathrm{H}_{2} \mathrm{O}_{2}$ elimination, they are also responsible for the reduction in glutathione and ascorbate which are essential for the continuity of the cycle [50]. Therefore, the inactivation of the APX and GR causes to the limitation of the elimination of the $\mathrm{H}_{2} \mathrm{O}_{2}$ in stressed plants $[49,50]$. The data of the present work showed that SDS caused serious reductions in both APX and GR activities. This means that SDS can interrupt the bio-regulation of the ascorbate-glutathione cycle.

\subsection{Effect of SDS applications on the reactive oxygen formation}

ROS are formed during the oxidation-reduction reaction of the electron transport events in cell organelles such as chloroplasts and mitochondria. They can function as signal molecules in the simulation of defence mechanisms against stress damages [11]. However, the formation of ROS may excessively increase due to the destructive effects of the stressors on the metabolic processes, including photosynthesis and respiration. In this case, the excessive ROS damages to all compartments of the cells [75]. The superoxide radical, the first radical product of the oxidation-reduction reactions, is a precursor molecule of other ROS leading to the irreversible degradation of macromolecules such as lipid, protein and carbohydrate and DNA $[46,49]$. In the present research, the amount of this radical showed an increase in depending on the SDS doses. Due to the disruption of the membrane lipids and proteins by SDS, this increase in superoxide formation may be attributed to the excessive electron leaks from the electron transport chains on cell membranes [37].

$\mathrm{H}_{2} \mathrm{O}_{2}$ is thought to be less toxic than the superoxide radical for cells since it has no free electrons. Meanwhile, when $\mathrm{H}_{2} \mathrm{O}_{2}$ is at low concentration, it functions as a signal molecule which stimulates the defence systems for stress tolerance $[7,10,31]$. Therefore, intracellular $\mathrm{H}_{2} \mathrm{O}_{2}$ content has to be always kept low by antioxidant enzymes. If the capacities of these enzymes are insufficient for the elimination of excessive $\mathrm{H}_{2} \mathrm{O}_{2}$, it transforms to hydroxyl radical which is the most dangerous radical for cell membranes [74]. In this case, the excessive $\mathrm{H}_{2} \mathrm{O}_{2}$ inevitably will lead protein denaturation, DNA breakage and lipid peroxidation $[31,51]$. The present study results showed the $\mathrm{H}_{2} \mathrm{O}_{2}$ contents increased with the rise of SDS concentration. It is strongly possible that these increases in $\mathrm{H}_{2} \mathrm{O}_{2}$ amounts are a result of SDS-induced decreases in CAT, APX and GR activities.

\subsection{Effect of SDS applications on the cell membrane}

The changes of the MDA amount are accepted as an indicator of the level of the lipid peroxidation which arises from reaction with ROS of the unsaturated bonds in phospholipids, cholesterol and fatty acids in the cell membrane. In the presence of ROS, lipid peroxidation continues in form of chaining on cell membranes and leads to the degradation of membrane integrity $[9,21,35]$. As far as we know, there are no studies reporting the effects on the plant cell membranes of SDS. The results of this study clearly showed that SDS caused to damage in the cell membranes as depending on the dose of the SDS. It is strongly possible that this damage in the membrane of barley seedlings was a result of the marked increase in ROS triggered by SDS.

In addition to this, another reason for the high membrane damage may be the fragmentation of peptide bonds of integral and peripheral proteins in the cell membrane by SDS. Some experiment evidence support the idea that 
SDS disrupted the peptide bonds of the integral proteins in the cell membranes cultivated in vitro $[25,43]$. The SDSinduced disruptions on the protein and membrane complex may also lead to the deterioration on membranes of the organelle such as chloroplast and mitochondria. In this case, the redox reactions in these organelle membranes are interrupted, and thus, ROS formation is excessively increased. When considering the compatible increase in the ROS and MDA results of the present study, it can be asserted that the high lipid peroxidation stemmed from the disruption of not only lipids but also proteins in the membranes by SDS.

\section{Conclusion}

Overall, the results of the present work revealed that SDS led to a clear negative effect on the physiological performance of barley seedlings. SDS reduced the biosynthesis of protein and photosynthetic pigments. In addition, SDS made difficult the control of ROS levels by decreasing the efficiency of antioxidant defence systems, and therefore, it caused serious damage in the cell membranes. As an inevitable result of these, it dramatically reduced the growth of barley seedlings. It is hoped that this study will draw attention to the necessity of the precautions against the random disposal into agricultural areas of wastewater containing SDS.

Acknowledgements This study was supported by a Grant from the research funds appropriated to Agri Ibrahim Cecen University, Agri, Turkey (Grant No. Agri-BAP MYO.17.003).

\section{Compliance with ethical standards}

Conflict of interest On behalf of all authors, the corresponding author states that there is no conflict of interest.

\section{References}

1. Abel PD (1974) Toxicity of synthetic detergents to fish and aquatic invertebrates. J Fish Biol 6(3):279-298

2. Agarwal S, Pandey V (2004) Antioxidant enzyme responses to $\mathrm{NaCl}$ stress in Cassia angustifolia. Biol Plant 48(4):555-560

3. Anderson JM, Boardman N (1966) Fractionation of the photochemical systems of photosynthesis I. Chlorophyll contents and photochemical activities of particles isolated from spinach chloroplasts. Biochim Biophys Acta BBA Biophys Photosynth 112(3):403-421

4. Arnon DI, Hoagland DR (1940) Crop production in artificial culture solutions and in soils with special reference to factors influencing yields and absorption of inorganic nutrients. Soil Sci 50:463-483

5. Atici GO (2016) Chemistry of surface active and their industrial applications. Technical University Foundation Publications, Istanbul, p 294
6. Baskin S, Salem H (1997) Oxidants, antioxidants and free radicals. CRC Press, Boca Raton, p 450p

7. Becker LB, Vanden Hoek TL, Shao ZH, Li CQ, Schumacker PT (1999) Generation of superoxide in cardiomyocytes during ischemia before reperfusion. Am J Physiol Heart Circ Physiol 277(6):2240-2246

8. Bettinger J, Gloor M, Gehring W (1994) Influence of a pretreatment with emulsions on the dehydration of the skin by surfactants. Int J Cosmet Sci 16(2):53-60

9. Blokhina O, Virolainen E, Fagerstedt KV (2003) Antioxidants, oxidative damage and oxygen deprivation stress: a review. Ann Bot 91(2):179-194

10. Bolwell GP, Bindschedler LV, Blee KA, Butt VS, Davies DR, Gardner SL, Minibayeva F (2002) The apoplastic oxidative burst in response to biotic stress in plants: a three-component system. J Exp Bot 53(372):1367-1376

11. Bowler C, Fluhr R (2000) The role of calcium and activated oxygens as signals for controlling cross-tolerance. Trends Plant Sci 5(6):241-246

12. Boyer JS (1982) Plant productivity and environment. Science 218(4571):443-448

13. Bozkurt A, Dural M, Yılmaz AB (2004) Some physico-chemical parameters and zooplankton (Rotifer, Cladoser and Copepod) fauna of Yarseli Dam Lake (Hatay/Turkey). Turk J Aquat Life 2(3):307-317

14. Bradford MM (1976) A rapid and sensitive method for the quantitation of microgram quantities of protein utilizing the principle of protein-dye binding. Anal Biochem 72(1-2):248-254

15. Bray EA (2000) Response to abiotic stress. In: Gruissem W, Jones $\mathrm{R}$ (eds) Biochemistry and Molecular Biology of Plants. American Society of Plant Physiologists, Rockville, pp 1158-1203

16. Brown V, Mitrovic V, Stark G (1968) Effects of chronic exposure to zinc on toxicity of a mixture of detergent and zinc. Water Res 2(4):255-263

17. Çakir E, Kivanç M (2000) Biodegradation of detergent active substances by bacteria isolated from Porsuk River. Anadolu Univ J Sci Technol 1(1):129-135

18. Cerdá A, Martínez V, Caro M, Fernández FG (2008) Effect of sulfur deficiency and excess on yield and sulfur accumulation in tomato plants. J Plant Nutr 7(11):1529-1543

19. Chang G, Zhang Q, Zhang L, Lü Y, Gao T (2015) Effects of sodium dodecyl sulfate on wheat (Triticum Aestivum L.) seedlings. Environ Prog Sustain Energy 34(4):1142-1147

20. Chaves MM, Flexas J, Pinheiro C (2009) Photosynthesis under drought and salt stress: regulation mechanisms from whole plant to cell. Ann Bot 103(4):551-560

21. Cross CE, Halliwell B, Borish ET, Pryor WA, Ames BN, Saul RL, Harman D (1987) OxygenRadicals and human disease. Ann Intern Med 107(4):526-545

22. Dirilgen N, Ince NL (1995) Inhibition effect of the anionic surfactant SDS on duckweed, with considerations of growth and accumulation. Chemosphere 31(9):4185-4196

23. Elstner EF, Heupel A (1976) Inhibition of nitrite formation from hydroxylammoniumchloride: a simple assay for superoxide dismutase. Anal Biochem 70(2):616-620

24. Erbil HY (2006) Surface chemistry of solid and liquid interfaces. Blackwell Publishing, England Wiley Online Library, Oxford, p 368

25. Fainerman V, Lylyk S, Aksenenko E, Petkov J, Yorke J, Miller R (2010) Surface tension isotherms, adsorption dynamics and dilational visco-elasticity of sodium dodecyl sulphate solutions. Colloids Surf A 354(1-3):8-15

26. Forni C, Braglia R, Harren F, Cristescu S (2012) Stress responses of duckweed (Lemna minor L.) and water velvet (Azolla filiculoides 
Lam.) to anionic surfactant sodium-dodecyl-sulphate (SDS). Aquat Toxicol 110:107-113

27. Forni C, Giordani F, Pintore M, Campanella L (2008) Effects of sodium dodecyl sulphate on the aquatic macrophytes Azolla and Lemna. Plant Biosyst Int J Deal Asp Plant Biol 142(3):665-668

28. Foyer $\mathrm{CH}$, Halliwell $B$ (1976) The presence of glutathione and glutathione reductase in chloroplasts: a proposed role in ascorbic acid metabolism. Planta 133(1):21-25

29. Gloor M, Wasik B, Gehring W, Grieshaber R, Kleesz P, Fluhr JW (2004) Cleansing, dehydrating, barrier-damaging and irritating hyperaemising effect of four detergent brands: comparative studies using standardised washing models. Skin Res Technol 10(1):1-9

30. Gong Y, Toivonen PMA, Lau OL, Wierman PA (2001) Antioxidant system level in 'Braeburn' apple in related to its browning disorder. Bot Bull Acad Sin 42:259-264

31. Hagar H, Ueda N, Shah SV (1996) Role of reactive oxygen metabolites in DNA damage and cell death in chemical hypoxic injury to LLC-PK1 cells. Am J Physiol Renal Physiol 271(1):209-215

32. Harinasut $P$, Poonsopa $D$, Roengmongkol K, Charoensataporn $R$ (2003) Salinity effects on antioxidant enzymes in mulberry cultivar. Sci Asia 29(10):109-113

33. Havaux M, Tardy F (1997) Thermostability and photostability of photosystem II in leaves of the Chlorina-f2 barley mutant deficient in light-harvesting chlorophyll a/b protein complexes. Plant Physiol 113(3):913-923

34. Heath RL, Packer L (1968) Photoperoxidation in isolated chloroplasts: I. Kinetics and stoichiometry of fatty acid peroxidation. Arch Biochem Biophys 125(1):189-198

35. Ho E, Galougahi KK, Liu CC, Bhindi R, Figtree GA (2013) Biological markers of oxidative stress: applications to cardiovascular research and practice. Redox Biol 1(1):483-491

36. Holdgate M (1979) A perspective on pollution. Cambridge University Press, Cambridge

37. Jifa W, Zhiming Y, Xiuxian S, You W, Xihua C (2005) Comparative researches on effects of sodium dodecylbenzene sulfonate and sodium dodecyl sulfate upon Lateolabrax japonicus biomarker system. Environ Toxicol Pharmacol 20(3):465-470

38. Kelly M, Altria K, Clark B (1997) Quantitative analysis of sodium dodecyl sulphate by capillary electrophoresis. J Chromatogr A 781(1-2):67-71

39. Kirsner RS, Froelich CW (1998) Soaps and detergents: understanding their composition and effect. Ostomy/Wound Manag 44(3A Suppl):62-69

40. Knight S, Andersson I, Branden Cl (1990) Crystallographic analysis of ribulose 1,5-bisphosphate carboxylase from spinach at $2.4 \AA$ resolution: subunit interactions and active site. J Mol Biol 215(1):113-160

41. Kremer ML (1970) Peroxidatic activity of catalase. Biochim Biophys Acta Enzymol 198(2):199-209

42. Kumar S, Thejasenuo JK, Tsipila T (2014) Toxicological effects of sodium dodecyl sulfate. J Chem Pharm Res 6:1488-1492

43. Laemmli UK (1970) Cleavage of structural proteins during the assembly of the head of bacteriophage T4. Nature 227(5259):680

44. Mariani L, De Pascale D, Faraponova O, Tornambe A, Sarni A, Giuliani S, Ruggero G, Onorati F, Magaletti E (2006) The use of a test battery in marine ecotoxicology: the acute toxicity of sodium dodecyl sulfate. Environ Toxicol 21(4):373-379

45. Mayer M, Bukau B (2005) Hsp70 chaperones: cellular functions and molecular mechanism. Cell Mol Life Sci 62(6):670

46. Mehdy MC (1994) Active oxygen species in plant defense against pathogens. Plant Physiol 105(2):467

47. Messina CM, Faggio C, Laudicella VA, Sanfilippo M, Trischitta F, Santulli A (2014) Effect of sodium dodecyl sulfate (SDS) on stress response in the Mediterranean mussel (Mytilus galloprovincialis): regulatory volume decrease (Rvd) and modulation of biochemical markers related to oxidative stress. Aquat Toxicol 157:94-100

48. Minareci O, Ozturk M, Egemen O, Minareci E (2008) The assessment of the effects of discharged of Manisa Municipality Wastewater Treatment Plant on Gediz River in terms of anionic detergent and phosphate parameters. Suleyman Demirel Univ Fac Arts Sci J Sci 3:16-25

49. Mittler R (2002) Oxidative stress, antioxidants and stress tolerance. Trends Plant Sci 7(9):405-410

50. Mittler R, Vanderauwera S, Gollery M, Van Breusegem F (2004) Reactive oxygen gene network of plants. Trends Plant Sci 9(10):490-498

51. Miyake C, Asada K (1992) Thylakoid-bound ascorbate peroxidase in spinach chloroplasts and photoreduction of its primary oxidation product monodehydroascorbate radicals in thylakoids. Plant Cell Physiol 33(5):541-553

52. Nakano Y, Asada K (1981) Hydrogen peroxide is scavenged by ascorbate-specific peroxidase in spinach chloroplasts. Plant Cell Physiol 22(5):867-880

53. Nisbet M, Verneaux J (1970) Composantes chimiques des eaux courantes. Discussion et proposition de classes en tant que bases d'interprétation des analyses chimiques. Annales de Limnologie-International Journal of Limnology, EDP Sciences

54. Niyogi KK (1999) Photoprotection revisited: genetic and molecular approaches. Annu Rev Plant Biol 50(1):333-359

55. Rajagopal S, Sudarsan N, Nickerson KW (2002) Sodium dodecyl sulfate hypersensitivity of clpP and clpB mutants of Escherichia coli. Appl Environ Microbiol 68(8):4117-4121

56. Rosety M, Ordoñez FJ, Rosety-Rodríguez M, Rosety JM, Rosety I, Carrasco C, Ribelles A (2001) Comparative study of the acute toxicity of anionic surfactans alkyl benzene sulphonate (ABS) and sodium dodecyl sulphate (SDS) on gilthead, Sparus aurata L., eggs. Histol Histopathol 16(4):1091-1096

57. Sergiev L, Alexieva E, Karanov E (1997) Effect of spermine, atrazine and combination between them on some endogenous protective systems and stress markers in plants. C R Acad Bulg Sci 51(3):121-124

58. Sharma SS, Dietz KJ (2006) The significance of amino acids and amino acid-derived molecules in plant responses and adaptation to heavy metal stress. J Exp Bot 57(4):711-726

59. Sharma P, Jha AB, Dubey RS, Pessarakli M (2012) Reactive oxygen species, oxidative damage, and antioxidative defense mechanism in plants under stressful conditions. J Bot 2012:1-26

60. Siegel S, Siegel B, Massey J, Lahne P, Chen J (1980) Growth of corn in saline waters. Physiol Plant 50(1):71-73

61. Sinclair S (1986) Oxygen, ischemia and inflammation. Acta Physiol Scand Suppl 548:9

62. Smith EL (1941) The action of sodium dodecyl sulfate on the chlorophyll-protein compound of the spinach leaf. J Gen Physiol 24(5):583

63. Soares C, Branco-Neves S, de Sousa A, Azenha M, Cunha A, Pereira R, Fidalgo $\mathrm{F}$ (2018) $\mathrm{SiO}_{2}$ nanomaterial as a tool to improve Hordeum vulgare L. tolerance to nano-NiO stress. Sci Total Environ 622:517-525

64. Soares C, Branco-Neves S, de Sousa A, Pereira R, Fidalgo F (2016) Ecotoxicological relevance of nano-NiO and acetaminophen to Hordeum vulgare L.: combining standardized procedures and physiological endpoints. Chemosphere 165:442-452

65. Soares C, de Sousa A, Pinto A, Azenha M, Teixeira J, Azevedo RA, Fidalgo $F$ (2016) Effect of 24-epibrassinolide on ROS content, antioxidant system, lipid peroxidation and Ni uptake in Solanum nigrum L. under Ni stress. Environ Exp Bot 122:115-125

66. de Sousa A, AbdElgawad H, Asard H, Pinto A, Soares C, BrancoNeves S, Braga T, Azenha M, Selim S, Al Jaouni S, Fidalgo F, Teixeira J (2017) Metalaxyl Effects on Antioxidant Defenses in Leaves and Roots of Solanum nigrum L. Front Plant Sci 8:1967 
67. de Sousa A, Teixera J, Regueiras MT, Azenha M, Silva F, Fidalgo F (2013) Metalaxyl-induced changes in the antioxidant metabolism of Solanum nigrum L. suspension cells. Pestic Biochem Phys 107:235-243

68. Switala J, Loewen PC (2002) Diversity of properties among catalases. Arch Biochem Biophys 401(2):145-154

69. Toroğlu E, Toroğlu S, Alaeddinoğlu F (2006) Water pollution in the Aksu river (Kahraman Maras). Turk J Geogr Rev 4:93-103

70. Tuna AL, Kaya C, Higgs D, Murillo-Amador B, Aydemir S, Girgin AR (2008) Silicon improves salinity tolerance in wheat plants. Environ Exp Bot 62(1):10-16

71. Witham FH, Blayles DF, Devlin RM (1971) Experiments in plant physiology. Van Nostrand, New York, p 245

72. Wolkoff $P$, Schneider T, Kildes $\varnothing$ J, Degerth R, Jaroszewski M, Schunk H (1998) Risk in cleaning: chemical and physical exposure. Sci Total Environ 215(1-2):135-156
73. Yee Y, Tam NFY, Wong YS, Lu CY (2003) Growth and physiological responses of two mangrove species (Bruguiera gymnorrhiza and Kandelia candel) to waterlogging. Environ Exp Bot 49(3):209-221

74. Young I, Woodside J (2001) Antioxidants in health and disease. J Clin Pathol 54(3):176-186

75. Zornoza P, Vázquez S, Esteban E, Fernández-Pascual M, Carpena $\mathrm{R}$ (2002) Cadmium-stress in nodulated white lupin: strategies to avoid toxicity. Plant Physiol Biochem 40(12):1003-1009

Publisher's Note Springer Nature remains neutral with regard to jurisdictional claims in published maps and institutional affiliations. 